Volume: 11 Issue: 1 Year: 2014

\title{
"It's so cold and impossible to make friends" Challenges of multicultural relationships in Finland
}

\author{
Jaana Anglé ${ }^{1}$ \\ Satu Uusiautti ${ }^{2}$ \\ Kaarina Määttä ${ }^{3}$
}

\begin{abstract}
This study focused on long-lasting multicultural relationships from Finnish spouses' perspectives. What are those special features that challenges multicultural relationships in Finland? The narrative method was used as the methodological approach. The research data were obtained through the use of narrative interviews with 11 Finnish people ( 8 women, 3 men). Every participant had been married to a foreign spouse for over 7 years (15 years on average). The results found describe everyday challenges as expressed by the Finnish spouses. Life in Finland, married to an immigrant, brought special challenges to the relationship, such as lack of knowledge of the Finnish language, religion, cultural traditions and roles, employment difficulties, and economic worries. Various life situations and threats from the environment were, however, handled so that the relationships lasted. In conclusion, models for the survival of multicultural marriages were introduced in this research. These include the stable relationship model, empowering relationship model, and relationship tinged with insecurity model.
\end{abstract}

Keywords: immigrant spouse, long-lasting marriage, multicultural marriage, narrative research

\section{Introduction}

Finland has had cultural minorities for centuries (McRae, 1997). However, in today's globalizing world, cultural encounters are more mundane than in those days. Therefore, it is important to understand events resulting from this phenomenon (Bras \& Kok, 2005). Modern Finnish people travel abroad in leisure and due to work-and so, the partner is often found elsewhere than from one's own home country (Williams, 2010).

About $13 \%$ of new marriages in Finland are multicultural; that means over 3,700 new multicultural marriages per year (Statistics Finland, 2013). This naturally means that many Finnish families have

\footnotetext{
${ }_{1}^{1}$ Ph.D., University of Lapland, jaana.angle@gmail.com

2 Ph.D., Adjunct Professor, University of Lapland, satu@,uusiautti.fi

${ }^{3}$ Ph.D., Professor, Vice-Rector, University of Lapland, Kaarina.Maatta@ulapland.fi
} 
Anglé, J., Uusiautti, S., \& Määttä, K. (2014). "It's so cold and impossible to make friends" Challenges of multicultural relationships in Finland. International Journal of Human Sciences, 11(1), 1198-1211. doi: 10.14687/ijhs.v11i1.2891

foreign relatives who may not always welcomed at first, but along with time, cultural differences get less attention than at the beginning of the multicultural relationship (Wong, 2003). From the point of view of the Finnish society, multicultural relationships face challenges in starting and adjusting to normal Finnish life. This is partly due to the wider scale of cultural practices than in traditional Finnish marriages. For example, gender-related tasks, child care, habits, and language can be seen differently in the new home country (Beck \& Beck-Gernsheim, 1995; Seol, 2009). Often the differences are quite visible, sometimes they are still unconscious. The visibility of cultural differences depends on how strongly the couple is biased toward one's or the other's culture. Differences can occur powerfully either at the beginning of the relationship or emerge in later phases. Immigrants tend to adjust to the mainstreaming culture more easily if their spouses represent the culture (Leinonen, 2003; Williams, 2010).

Divorces in multicultural marriages have become more and more common during the past decades, as have divorces in general (Heikkilä, 2011; Kiiski, Uusiautti, \& Määttä, 2013). Quite frequently, problems and difficulties in these marriages are analyzed, but that is just one side of the coin: multicultural marriages also include much positive that do not exist in marriages of two original inhabitants (Davidson, 1992; Williams, 2010). Every relationship has its own challenges. Multicultural relationships offer a rich cultural background to families' everyday lives (Gaines \& Brennan, 2001). In some situations, couples might not share the understanding, and different viewpoints can cause conflicts. Contradictory ways of seeing and acting in problematic situations can cause cultural clashes (Kalmijn, 2007). This study focused on challenges of multicultural marriages from the point of view of their stability.

Reuben Hill (1949; 1958) pioneered in family research by studying families during the Second World War while men left families and came back. According to Hill (1949), families face stressful situations in various phases of life, cause by inner or outer factors and events. Crises emerging inside a family cover, for example, alcohol abuse or mental and physiological illnesses. Crises such as unemployment or economic difficulties come from outside a family. Uncertainty and confusion create new behavioral models and roles in families. The first adjustment phase starts from the individual, the nature of the crisis, and how the individual adjusts to the situation. The second phase is related to the spouses and how they as a couple adjust to the situation. The third phase involves the whole family and the roles emerging in the family due to the crisis (Hill, 1949). During the adjustment period, the family breaks and surpasses its old habits and learns new daily routines. Likewise, the couple-identity and intimacy can change. It is likely that the relationship between parents and children change depending on the synergy of the family (Hill, 1949). 
Anglé, J., Uusiautti, S., \& Määttä, K. (2014). "It's so cold and impossible to make friends" Challenges of multicultural relationships in Finland. International Journal of Human Sciences, 11(1), 1198-1211. doi: 10.14687/ijhs.v11i1.2891

Hill (1949; 1958) introduces three different family models which each can lead to a long-lasting relationship. The first is the patriarchal family in which the man is the authoritative figure. The second is the matriarchal family in which the man earns keep but does not have any further responsibilities. The third is the democratic family in which the man, woman, and other family members share responsibilities (Hill, 1949). Öyster G. Holter (2000) also distinguishes three family types. The first is paternalist patriarchy which represents similar male-dominating family as Hill's first family type. While Hill's family type is pre-industrial, but according to Holter, these family models still exist in even western societies too. The second family types in Holter's model is based on equality and is called "masculine patriarchy". The man in family bears the responsibility of earning keep while the woman has stayed home and takes care of children if they have any. The third type is androgyny patriarchy in which the woman participates actively in work life and public tasks and the man participates and bears responsibility for family life as well (Holter, 2000). Indeed, crucial to the stability of a relationship is the spouses' mutual agreements on their roles (Määttä \& Uusiautti, 2013a) and ability to compromise (Määttä \& Uusiautti, 2012; Uusiautti \& Määttä, 2012). In all, the secrets of long-lasting relationships have been studied abundantly and explained with numerous theories (see Määttä \& Uusiautti, 2013a).

Gottman (1993; 1994; Gottman \& Notarius, 2002) points out how family crises often emerge because of dysfunctional family communication. Ability to positive interacting, successful problemsolving, empathizing, and listening to the other are important factors of satisfaction in romantic relationships (Määttä \& Uusiautti, 2013b). Hill (1949) continued by claiming that the ability to nurture relationship develops already in childhood. Love skills are learnable and similar to virtue, note Uusiautti and Määttä (2011). Bowlby's (1988) famous theory on intimate relationships emphasizes childhood care experiences as the basis of romantic relationships and self-appreciation in adulthood. Adults' affection styles can be divided, for example, into four: safe, clinging, timid, or self-satisfied depending on how positive or negative impression one has about oneself and others. For example, Figley and McCubbin (1983) note that norms learned in childhood are manifested as various traditions, habits, attitudes, and values. These values can be similar to one's parents or totally different. However, these models can be seen as innate, guiding our behavior in different situations and contexts (Figley \& McCubbin, 1983). The ability to adjust to changes (Perrone, Wright, \& Jackson, 2009; Riehl-Ende, Thomas, \& Willi, 2003) and tolerate conflicts (Meyer et al., 2014) as well as problem-solving skills (Rosenthal \& Eckstein, 2013) are important, although they hardly along explain the stability of a relationship. 
Anglé, J., Uusiautti, S., \& Määttä, K. (2014). "It's so cold and impossible to make friends” Challenges of multicultural relationships in Finland. International Journal of Human Sciences, 11(1), 1198-1211. doi: 10.14687/ijhs.v11i1.2891

A multicultural relationship face special challenges that depend on the culture of the country the couple lives. Finland provides special environment to multicultural relationships: It is a small country by area and with about only 5.5 million inhabitants. It is located on the Arctic Circle and thus has long, dark, and cold winters. Summers are short but bright, round-the-clock. The population of Finland is relatively homogenous and highly educated. The level of technology is high. The Finnish language differs considerably from western languages by its vocabulary and grammar, and thus, it is quite difficult to learn. In this article, we analyze how Finland appears from the perspective of a multicultural relationship.

\section{Method}

Public discussion can easily give an impression that multicultural marriages would be specifically sensitive to break-ups. Indeed, multiculturalism sets some challenges to relationships, and even if divorces were common, there are also relationships that last (Donovan, 2004; Heikkilä, 2011; Karney \& Bradbury, 1995; Määttä \& Uusiautti, 2013a; Tucker \& Crouter, 2008). This viewpoint forms the basis of this study that focused on marriages between spouses from different cultures. The starting point is partly problem-focused but the phenomenon is approached in a solutioncentered manner: what factors explain the stability of a relationship as described by spouses themselves?

In Finland, multicultural marriages are often studied from the point of view of acculturation process (e.g., Tuomi-Nikula, 1997). Immigration researchers have focused on analyzing the dynamics and daily stress situations in multicultural relationships (e.g., Bisin \& Verdier, 2000; Celikaksoy, Nielsen, \& Verner, 2006; Williams, 2010; Wong, 2003). The purpose of this study was to find out what are the challenges, conflicts, and threats of multicultural relationships in Finland. The viewpoint is limited to Finnish spouses living in multicultural relationships asking how they perceive the challenges after starting family life in Finland with a spouse from a different culture.

The Finnish spouses were recruited in this study across Finland. The criterion was that they had to be married for about 15 years with a foreign spouse. The recruitment of interviewees happened partly with the so-called snowball method: some of the interviewees were found with the help of another interviewee. Altogether, 14 spouses were reached and interviewed, but only eleven interviews were used as the data of this study. The interviewees represented both women $(\mathrm{N}=8)$ and men $(\mathrm{N}=3)$, aged 32-51. They were all born in Finland and are Finnish citizens, and married to a foreign spouse. The focus on the Finnish spouses was justified also with language: if the foreign spouses were interviewed, many of the interviews would be done with an interpreter which might have influenced the depth and openness of interviews. In this study, it is also impossible to reveal 
Anglé, J., Uusiautti, S., \& Määttä, K. (2014). "It's so cold and impossible to make friends" Challenges of multicultural relationships in Finland. International Journal of Human Sciences, 11(1), 1198-1211. doi: 10.14687/ijhs.v11i1.2891

the foreign spouses countries of origin or continents in order to protect their anonymity. However, the relationships represent countries and cultures across the world.

The narrative interviewing method was chosen to this study (Lieblich, Tuval-Mashiac, \& Zilber, 1998; Polkinghorne, 1995). Narratives are considered data that participate in forming and producing culture, identities, and political projects. Before going to asking how to do research with narratives, it is important to realize what narratives are and how narratives work in the social life (Bruner, 1986; Gudmundsdottir, 1996). For example, Koski (2007) divides the concept of narrative into four, partly overlapping juxtapositions: (1) singular, designated narratives vs. narrative as a theoretical concept; (2) narrative as a research target vs. narrative as a methodological tool for analyzing a phenomenon produced by narrating; (3) the definition of narrative based on its form vs. its content; and (4) narrative as a concrete expression vs. narrative as a mere metaphor describing human activity.

Narrative research has developed during past decades, but it cannot be seen as a coherent paradigm or method (Heikkinen, 2002). Merely, narrative is a framework for research related to narratives. These studies share the position of narratives in transmitting and constructing of reality. It means that a narrator has a central role between the reality and narrative (Bal, 1999).

The data were analyzed with the methods of narrative analysis and analysis of narratives (Polkinghorne, 1995). The analysis of narratives focused on analyzing the contents of narratives. The narrative analysis analyzed the data as a whole by categorizing by themes and types. Elements emerging from narratives were organized into a new, comprehensive narrative. Each interview were formed into a narrative and then these narratives were combined into a meta-narrative that was compared to the interviewees' stories. Similarities and differences were analyzed from narratives (Lieblich, Tuval-Mashiac, \& Zilber, 1998). In the analysis of narratives, interview data were categorized into main and sub categories in the light of research tasks and themes.

\section{Results: Challenges of multicultural relationships in Finland}

The interview data showed that the challenges differed according to the background of the interviewees' spouses. The foreign spouses could be divided into two groups, each of which are treated differently in Finland. The first group covers white, western, English-speaking spouses. The second group consists of spouses without language skills and who come from developing countries. When arriving to Finland, they are in an unequal position due to, for example, the expectation of their language skills: while the spouses representing the first group might not be expected to know Finnish, the spouses from the second group were. The spouse's initial status seemed to determine 
Anglé, J., Uusiautti, S., \& Määttä, K. (2014). "It's so cold and impossible to make friends" Challenges of multicultural relationships in Finland. International Journal of Human Sciences, 11(1), 1198-1211. doi: 10.14687/ijhs.v11i1.2891

the level of challenges. The status includes language skills, age, education, home background, occupation, mobility, and cultural knowledge about one's own country and Finland. A high initial status gives better chances to cope with the possible problems the multicultural relationship faces (see Tuomi-Nikula, 1997). The challenges, thus, varied by level and number in multicultural relationships. Next, the challenges emerging in the data are introduced.

\section{Getting the residence permit}

The immigration legislation of Finland is strict due to which Finland has relatively few immigrants. The interviewees criticized the Finnish authorities and bureaucracy. Getting the residence permit could take months being not only challenging but also made integration to Finland more difficult (see also Fingerroos \& Haanpää, 2011).

"The spouse had to apply for the residence permit from his home country; we had to fly there to his country and wait for a rough month there while the application was processed... Still, we had to try to plan our life forward... Studies started at the beginning of September, and that made the processing faster here.” (Woman No. 8)

Before receiving the permit, the couple lives in uncertainty and life is overshadowed by the threat of losing the loved. Breger and Hill (1998) noted that the non-typical the foreign spouse is, the more the state tries to control the relationship. Breger and Hill's finding supports the results of this study, too. Many researchers refer to immigrants by marriage, including fake marriages (Zhang \& Kline, 2009). These marriages aim to permanent residence permits and are controlled strictly.

"So we had to go through a sort of investigation into whether we are a real married couple or not." (Man No. 1)

A marriage between two Finnish people is not probably controlled as strictly as a marriage between a foreigner and a Finn. Finnish people's individual choices are not questioned by the legislation, and thus, relationships with foreigners are unequal to relationships between Finns. It tested spouses' patience.

"Adversities and everything... Some people have told that they would probably have given up already at the onset." (Woman No. 8)

\section{Integration to Finland}

Starting life in Finland differed among the interviewees based on their spouses' knowledge about Finland. Relationships in this study were constructed differently in Finland. The first group was spouses who came to Finland as total foreigners, without any knowledge about Finland and the Finnish language. They knew about Finland only what their Finnish spouses had told them. The 
Anglé, J., Uusiautti, S., \& Määttä, K. (2014). “It's so cold and impossible to make friends” Challenges of multicultural relationships in Finland. International Journal of Human Sciences, 11(1), 1198-1211. doi: 10.14687/ijhs.v11i1.2891

second group covered spouses who knew something about Finland, while the third group of spouses had already lived in Finland when the spouses met each other.

The interviewees described how moving to Finland had been exotic to their spouses at first. Their narratives showed how their spouses had been fascinated by the beautiful and pure nature, excited about Finnish people, and enthusiastic about making their new homes. After the initial excitement had calmed down, everyday life and possible difficulties in finding employment and making friends started to annoy the spouses. Finland and Finnish people were seen negative, and the nature that was first marveled started to appear annoying. Rough weather and various difficulties influenced the way the foreign spouses saw Finnish people too: as Finns were first considered polite and smiling, now they appeared impolite, unsocial, and racist. Total foreigners had not necessarily been able to be prepared to the difficult language, cold winter, and unemployment.

"The spouse started to hate Finland; this was a horrible place... It's so cold and impossible to make friends." (Woman No. 1)

Learning the new, difficult language and culture can be challenging. In addition, being able to act in the society like other Finnish citizens seemed crucial. Integration becomes more difficult if one cannot act as a full member of society. This is, however, not the case until becoming a citizen. For example, political activity is impossible without citizenship among others. This keeps immigrant spouses detached from and outsiders of society (see also Leinonen, 2011; Williams, 2010). In this study, the feeling of outsider was expressed, for example, as follows:

"You are basically nobody if you cannot do the same things than others... when others talk about something, about doing this or that, my spouse felt unequal..." (Man No. 2)

\section{The Finnish spouse's burden}

The problems in the beginning, applying for the residence permit, and the spouse lacking knowledge of the Finnish language caused conflicts in the relationships. In many families, the Finnish spouse had been taking care of their common and the foreign spouse's own matters. They also had been acted as interpreters.

"It would not have worked if I had not taken care. I worked and the other just stayed in this little apartment... Amidst everything, I tried to take care of my spouse's businesses too. So it was something that started to get tired of it at some point." (Woman No. 7)

The role of handling everything was experienced as hard, especially if it had lasted for years. Without the Finnish language skills, the foreign spouse's integration was not good. The spouses 
Anglé, J., Uusiautti, S., \& Määttä, K. (2014). "It's so cold and impossible to make friends" Challenges of multicultural relationships in Finland. International Journal of Human Sciences, 11(1), 1198-1211. doi: 10.14687/ijhs.v11i1.2891

missed many opportunities and did not become employed easily. Those who cope with English coped better and got employed in some fields, but still they could miss their home country or want to move to a third country (cf., Leinonen, 2011).

The first years in Finland and being married had been the most challenging to the interviewees and their spouses. Moving in Finland and adjusting to the new situation with a new spouse were huge changes in life. The Finnish spouse sometimes felt feelings of insufficiency and guilt, because he or she had to be able to take care of them and be strong.

"I think it was the second year in Finland when I felt that everything is falling down... I worked like a dog, and the spouse was not at home much, and I took care of all practical matters... and then we had the first crisis in our relationship. And, I started to solve my own life... and I wanted to move elsewhere (in Finland).” (Woman No. 2)

The Finnish spouse can frustrate in a situation of being obliged to take care of practical affairs for the other. On the other hand, the foreign spouse can feel frustrated and inferior because of being dependent on the Finnish spouse.

"I handled all insurances and bank affairs, and all phone calls. It started to be laborious and so it became our constant fight.” (Woman No. 2)

Indeed, it seemed that spouses in multicultural marriages have constant unspoken discussions about interaction, beliefs, feelings, and changing behaviors to balance their life together.

\section{The foreign spouse stands out from Finns}

The foreign spouse being different from the Finnish people was considered contradictory: on the one hand, difference was seen interesting and appealing, positive and completing oneself (Määttä \& Uusiautti, 2013c):

"When we met, I thought 'is this person for real'! He was so different..." (Woman No. 6)

The Finnish spouses compared the foreign spouses with Finnish ones and appreciated the dissimilarity of their spouse.

"My spouse is clearly dissimilar to Finns" (Man No. 3)

On the other hand, the spouse's different temperament and looks as well as social behaviors (loquacity, expressions of affection) caused also isolation and difficulties in adjusting to the Finnish living environment. Dissimilarity can be stigmatized non-conventional because some characteristics do not fit to the expectations of the environment. Therefore, these features can become targets of powerful change, too. 
Anglé, J., Uusiautti, S., \& Määttä, K. (2014). "It's so cold and impossible to make friends” Challenges of multicultural relationships in Finland. International Journal of Human Sciences, 11(1), 1198-1211. doi: 10.14687/ijhs.v11i1.2891

The interviews included two distinguishing viewpoints. According to the first, the foreign spouse is always sort of a stranger in Finland. According to the second, the foreign spouse has become one of the Finns. Those who represented the latter viewpoint had been married longer and tended to minimize their spouses' backgrounds. On the other hand, they can also try to keep quiet about all such negative issues that might refer to the specialty or complexity of their marriage.

\section{Daily problems}

Every relationship has everyday problems; they cannot be avoided nor can we claim that original inhabitants' relationships would be easier than multicultural relationships when it comes to daily chores and problems. In the data of this study, conflicts were caused by little, mundane issues or by bigger themes, such as language, pressure by the environment, fear of physical or mental violence, financial issues, or communication between spouses.

Spouses' expectations about their roles in marriage could differ considerably. At work, the foreign spouse has to adjust to the Finnish culture, but at home, he or she expects the Finnish spouse to follow the habits of his or her culture. However, many interviewees talked about shared values and cosmopolitanism. Relatives and childhood family either helped or increased problems.

"It was hard because my relatives did not support us. They hoped my spouse would find someone else and even doubted his honesty and everything, even though there was no reason." (Woman No. 6)

Due to tension and stress, the spouses could turn to various forms of exercising power: physical violence, manipulation, persuasion, the silent treatment, cheating, etc. Inability to solve problems successfully challenged the relationships. Families in which the foreign spouse had not learned the Finnish language or finding employment was difficult saw moving elsewhere in Finland or from Finland as the solution that would improve the quality of life. The stability of relationship was tested by uncertainty of whether the future would be in Finland after all.

"But, however, the spouse was quite isolated and did not have much meaningful doing... He was in horrible crisis, not being able to live in Finland, not being able to tolerate this any longer. The spouse thought that his life was wasted, the years in Finland were wasted..." (Woman No. 2)

\section{Conclusions}

The purpose of this study was to analyze the challenges of multicultural marriage in Finland. The focus was on long-lasting marriages as the interest was in how the spouses adjust to challenges and how powerfully the challenges test the relationships. Three types of multicultural relationships were distinguished based on the results: the stable relationship, empowering relationship, and 
Anglé, J., Uusiautti, S., \& Määttä, K. (2014). "It's so cold and impossible to make friends" Challenges of multicultural relationships in Finland. International Journal of Human Sciences, 11(1), 1198-1211. doi: 10.14687/ijhs.v11i1.2891

relationship tinged with insecurity. These types sum up and concretize the challenges the couples had faced during their years in Finland.

The stable relationship type refers to couples who had been married about 15 years. The most crises were faced mostly during the first years of their relationship when starting a family together. Clashes were caused by differences in temperaments and normal relationship issues. The environment had supported the positive development of the relationship. Spouses' roles had changed and developed flexibly during changes in life, and they had negotiated about their roles constantly. Positive attitudes had helped coping with stressful situations in life, and problems were seen nothing more than a natural part of everyday life.

The empowering relationship type covers relationships that have developed fast since the first meeting. They resemble narratives of destiny. These marriages had lasted over 20 years. Integration in Finland had been challenging because of the foreign spouse's lack of language skills and unemployment. The core of this narratives is in the change and development in spouses, understanding of the other. Threats to these relationships came mostly, for example, in the forms of negative attitudes of childhood families or intrinsic limitations of development. What these marriages had in common was their constant struggle for preserving the relationship. At the beginning of the relationships, these couples had followed mainly the foreign spouse's cultural habits and traditions illustrating open, patriarchal arrangement with male domination. However, the roles had become more balanced in the course of time.

The relationship tinged with insecurity refers to marriages that had lasted ten years or less. According to the narratives, these couples were open to the opportunities offered by the globalizing world and some of them were planning to move abroad. Relationships had developed fast from dating into marriages. Language problems, economic problems, and problems in mutual trust had been putting a strain on the relationship. The gender roles were natural in these relationships with no distinct women's and men's duties. The Finnish spouses were burdened with responsibilities. In some of these relationships, the immigrant spouses had not learned the Finnish language making integration more difficult. Most of the spouses came, however, from developed countries and could speak English. Marriages in this group were going through a crisis or had just coped with one, and, thus, the interview took place during a time of reconstructing the relationship. New life was often seen somewhere else than in the current place of residence (see also Lee \& Piper, 2003). 
Anglé, J., Uusiautti, S., \& Määttä, K. (2014). “It's so cold and impossible to make friends” Challenges of multicultural relationships in Finland. International Journal of Human Sciences, 11(1), 1198-1211. doi: 10.14687/ijhs.v11i1.2891

\section{Discussion}

What is common to the narratives in this study, first, is the importance of language skills, especially the Finnish language. Immigrant spouses may not realize, for example, how significant role the knowledge of Finnish language can be for becoming employed. In addition to employment, socializing and familiarizing with the Finnish culture can become frustrating and difficult, which is a notion supported in other studies about immigrants' integration to their new countries of residence (see e.g., Breger \& Hill, 1998; Cools, 2011).

Language makes a salient part of culture; it is the way to understand and learn about the culture (e.g., Norton, 1997). Although in Finland, people can manage relatively well with English, Finnish language skills probably can offer wider opportunities for employment and participation in society (Schumann, 1986). However, it is worth remembering that attempts and efforts to integrate in the new home country do not mean that one should forget his or her own culture. For balance life and healthy cultural identity, also in marriage, one should pursue balance with one's own and the spouse's culture. Multiculturalism in a relationship can turn into an empowering richness when the suitable balance in found (Padilla \& Perez, 2003) — and every couple has to find their own way to the successful combination of their cultures.

The process of learning about the culture and molding values, attitudes, and behavior can be seen as a two-level acculturation at micro and macro levels (see e.g., Kisselev, Brown, \& Brown, 2010; Tucker \& Crouter, 2008; Tuomi-Nikula, 1997). At the macro level, the immigrant has to acculturate into the society and culture of the new country of residence. Whereas at the micro level, both spouses have to familiarize with each other's understanding about marriage and spouses' roles, values and expectations. This happens regardless of the state, and can occur by over-emphasizing the other's culture at home. If the spouses find a balance and space for both cultures, a so-called third culture is born (Tuomi-Nikula, 1997). Spouses form a multicultural identity rather than an identity based on just their own cultural tradition (see e.g., Jensen, 2003). Mixing up spouses cultures can create new habits and traditions in the family and turn into most satisfying outcome.

Acculturation can be stressful (Berry, 1997) and lead to extreme ways of releasing frustration and negative feelings while others cope with adversities better (e.g., Scott, 2001). According to Padilla and Perez (2003), acculturation is more difficult for those persons who must cope with the stigma of being different because of skin color, language, ethnicity, and so forth, and as showed in this study, this concerns also multicultural relationships greatly. Could problems in multicultural marriages be avoided at the time of adjusting in the new home country and starting a family? Hardly, but knowledge about possible adversities and other couples having gone through the same 
Anglé, J., Uusiautti, S., \& Määttä, K. (2014). "It's so cold and impossible to make friends” Challenges of multicultural relationships in Finland. International Journal of Human Sciences, 11(1), 1198-1211. doi: 10.14687/ijhs.v11i1.2891

situation can help. The purpose of this study is to highlight the positive viewpoint and survival, and give hope for multicultural relationships by introducing experiences of couples who have managed to create stable, long-lasting marriages. Mutual acceptance and understanding, perseverance, and personal mental growth can form the basis of a stable marriage (Gaines \& Brennan, 2001). A spouses' different background can also strengthen a marriage.

\section{References}

Bal, M. (1999). Narratology: Introduction to the theory of narrative. (2nd ed.) Toronto: University of Toronto Press. Beck-Gernsheim, E., \& Beck, U. (1995). The normal chaos of love. Cambridge: Polity Press.

Bisin, A., \& Verdier, T. (2000). Beyond the melting pot: Cultural transmission, marriage, and the evolution of ethnic and religious traits. Quarterly Joumal of Economics, 115, 955-988.

Bowlby, J. (1988). A secure base. New York, NY: Basic Books.

Bras, H., \& Kok, J. (2005). "They live in indifference together": Marriage mobility in Zeeland, The Netherlands, 1796-1922. International Review of Social History, 50(13), 247-274.

Breger, R., \& Hill, R. (1998). Cross-cultural marriage. Identity and choice. New York, NY: Berg.

Bruner, J. S. (1986). Actual minds, possible worlds. Harvard, MA: Harvard University Press.

Celikaksoy, A., Nielsen, S., \& Verner, M. (2006). Marriage migration: Just another case of positive assortative matching? Review of Economics of the Household, 4(3), 253-275.

Cools, C. (2011). Relational dialects in intercultural couples' relationships. (Jyväskylä Studies in Humanities, 171). Jyväskylä: Jyväskylä University Press.

Davidson, J. R. (1992). Theories about black-white interracial marriage: A clinical perspective. Journal of Multicultural Counseling and Development, 20(4), 150-157. doi: 10.1002/j.2161-1912.1992.tb00573.x

Donovan, S. (2004). Stress and coping techniques in successful intercultural marriages. (Virginia Polytechnic Institute and State University, Falls Church, VA.)

Figley, C. R., \& McCubbin, H. I. (1983). Stress and the family. Vol. II: Coping with the catastrophe. New York, NY: Brunner.

Fingerroos, O., \& Haanpää, R. (2011). Strangers from the East-Narratives of Karelian exiles and reimmigrants from Russia Regarding their integration in Finland. In. I. G. Rozenberga \& M. Zirnite (Eds.), Oral history: Migration and local identities (pp. 193-211). Latvia: University of Latvia.

Gaines, S. T., \& Brennan, K. A. (2001). Establishing and maintaining satisfaction in multicultural relationships. In J. Harvey \& A. Wenzel (Eds.), Romantic relationships. Maintenance and enhancement (pp. 237-254). Mahwah, NJ: Taylor \& Francis.

Gottman, J. M. (1993). A theory of marital dissolution and stability. Journal of Family Psychology, 7(1), 57-75.

Gottman, J. M. (1994). What predicts divorce? The relationships between marital process and marital outcomes. Hillsdale, NJ: Erlbaum.

Gottman, J. M., \& Notarius, C. I. (2002). Marital research in the 20th century and research agenda for the 21st century. Family Process, 41(2), 159-197. doi: 10.1111/j.1545-5300.2002.41203.x

Gudmundsdottir, S. (1996). The teller, the tale, and the one being told: The narrative nature of the research interview. Curriculum Inquiry, 26(3), 293-306.

Heikkinen, H. L. T. (2002). Telling stories in teacher education. A Narrative-biographical view of Portfolio Work. In R. Huttunen, H. L. T. Heikkinen, \& L. Syrjälä (Eds.), Narrative research. Voices of teachers and philosophers (pp. 123-132). Jyväskylä: Sophi. 
Anglé, J., Uusiautti, S., \& Määttä, K. (2014). “It’s so cold and impossible to make friends” Challenges of multicultural relationships in Finland. International Journal of Human Sciences, 11(1), 1198-1211. doi: 10.14687/ijhs.v11i1.2891

Hill, R. (1949). Families under stress. Adjustment to the Crises of war separation and reunion. New York, NY: Harper $\&$ Brothers.

Hill, R. (1958). Generic features of families under stress. Social Casework, 49, 139-150.

Holter, Ö. G. (2000). Masculinities in context: on peace issues and patriarchal orders. In I. Breines, R. Connell, \& I. Eide (Eds.), Male roles, masculinities and violence. A culture of peace perspectives (pp. 61-83). Vendöme: Unesco Publishing.

Heikkilä, E. (2011). Multicultural marriages and their dynamics in Finland. In E. Heikkilä \& B. S. A. Yeoh (Eds.), International marriages in the time of globalization (pp. 89-102). New York, NY: Nova Science Publishers.

Jensen, L. A. (2003). Coming of age in a multicultural world: Globalization and adolescent cultural identity formation. Applied Developmental Science, 7(3), 189-196.

Kalmijn, M. (2007). Explaining cross-national differences in marriage, cohabitation, and divorce in Europe, 1990-2000. Population Studies, 61 (63), 243-263.

Karney, B. R., \& Bradbury, T. N. (1995). The longitudinal course of marital quality and stability: A review of theory, method and research. Psychological Bulletin, 111, 3-34.

Kiiski, J., Määttä, K., \& Uusiautti, S. (2013). "For better and for worse, or until...”: On divorce and guilt. Journal of Divorce \& Remarriage, 54(7), 519-536. doi: 10.1080/10502556.2013.828980

Kisselev, P., Brown, M. A., \& Brown, J. D. (2010). Gender differences in language acculturation predict marital satisfaction: A dyadic analysis of Russian-speaking immigrant couple in the United States. Journal of Comparative Family Studies, 41, 767-782.

Koski, K. (2007). Katsaus: Mikä kertomus on? Tieteidenvälisyyden haasteita "kertomusten" tarkastelussa [Review: What is a narrative? The challenges of interdisciplinarity in analysis of "narratives"]. Elore, 14(1), 111.

Lee, M., \& Piper, N. (2003). Reflections on transnational life-course and migratory patterns of middle-class women. Preliminary observations from Malaysia. In N. Piper \& M. Roces (Eds.), Wife or worker? Asian women and migration (pp. 121-136). Lanham, MD: Rowman \& Ligglefield.

Leinonen, J. (2003). Avioelämää Amerikan mantereella. Pohjois-Amerikassa avioituneiden suomalaisnaisten sopeutumisesta [Marriage life in the American continent. On adjustment in Finnish women becoming married in North America]. Siirtolaisuus - Migration, 30(1), 3-13.

Leinonen, J. (2011). Elite migration, transnational families, and the nation state: International marriages between Finns and Americans across the Atlantic in the twentieth century. Minneapolis, MN: University of Minnesota.

Lieblich, A., Tuval-Mashiach, R., \& Zilber, T. (1998). Narrative research. Reading, analysis, and interpretation. Thousand Oaks, CA: Sage.

McRae, K. D. (1997). Conflict and compromise in multilingual societies: Finland. Waterloo: Wilfrid Laurier University Press.

Meyer, R. A., Williams, R. C., Haley, M., Brownfield, J. N., McNicols, K. B., \& Pribozie, N. (2014). Crisis intervention with families. Assessing changes in family characteristics. The Family Journal, 22(2), 179-185. doi: $10.1177 / 1066480713513551$.

Määtä, K., \& Uusiautti, S. (2012). Seven rules on having a happy marriage along with work. The Family Journal, 20(3), 267-273. doi: 10.1177/1066480712448997

Määttä, K., \& Uusiautti, S. (2013a). Many faces of love. Rotterdam: Sense Publishers.

Määttä, K., \& Uusiautti, S. (2013b). Silence is not golden: review of studies of couple interaction. Communication Studies, 64(1), 33-48. doi: 10.1080/10510974.2012.731467

Määttä, K., \& Uusiautti, S. (2013c). Who is the one? The Difficulty in selecting the Partner. In: Kaarina Määttä \& Satu Uusiautti (Eds.), Many faces of love (pp. 19-39). Rotterdam: Sense Publishers.

Norton, B. (1997). Language, identity, and the ownership of English. TESOL Quarterly, 31(3), 10-30. 
Anglé, J., Uusiautti, S., \& Määttä, K. (2014). "It's so cold and impossible to make friends” Challenges of multicultural relationships in Finland. International Journal of Human Sciences, 11(1), 1198-1211. doi: 10.14687/ijhs.v11i1.2891

Padilla, A. M., \& Perez, W. (2003). Acculturation, social identity, and social cognition: A new perspective. Hispanic Journal of Behavioral Sciences, 25(1), 35-55. doi: 10.1177/0739986303251694

Perrone, K. M., Wright, S. L., \& Jackson, Z. V. (2009). Traditional and nontraditional gender roles and workfamily interface for men and women. Journal of Career Development, 36(1), 8-24.

Polkinghorne, D. E. (1995). Narrative configuration in qualitative analysis. In J. A. Hatch \& R. Wisniewski (Eds.), Life history and narrative (pp. 5-23). London: Routledge.

Riehl-Emde, A., Thomas, V., \& Willi, J. (2003). Love: An important dimension in marital research and therapy. Family Process, 42(2), 253-267.

Rosenthal, S., \& Eckstein, D. (2013). Two couples' problems-solving activities. The 1-hour conference and a six-step dialectical method. The Family Journal, 21 (3), 342-346. doi: 10.1177/1066480713479303

Schumann, J. H. (1986). Research on the acculturation model for second language acquisition. Journal of Multilingual and Multicultural Development, 7(5), 379-392. doi: 10.1080/01434632.1986.9994254

Scott, J. (2001). Power. Cambridge: Polity.

Seol, D.-H. (2009). Child raising and education of marriage-based immigrants in Korea: On the focus of infants. Korean Journal of Pediatric, 52(4), 403-409. doi: 10.3345/kjp.2009.52.4.403

Statistics Finland. (2013). Ulkomaalaiset ja siirtolaisuus [Foreigners and immigration]. Helsinki: Statistics Finland.

Tucker, M. B., \& Crouter, A. C. (2008). Enduring couples in varying sociocultural contexts. Family Relations, 57(2), 113-116. doi: 10.1111/j.1741-3729.2008.00487.x

Tuomi-Nikula, O. (2007). Kaksikulttuurinen perhe eurooppalaisen etnologian tutkimuskohteena [Bicultural family as the research target of European ethnology]. In T. Korhonen \& P. Leimu (Eds.), Näkökulmia kulttuurin tutkimukseen [Viewpoints to cultural research] (pp. 269-298). Turku: Painosalama.

Uusiautti, S., \& Määttä, K. (2011). The ability to love - A virtue-based approach. British Journal of Educational Research, 2(1), 1-19.

Uusiautti, S., \& Määttä, K. (2012). The successful combination of work and family in Finland: The ability to compromise as the key factor. Journal of Comparative Family Studies, 43(2), 151-163.

Williams, L. (2010). Global marriage. Cross-border marriage migration in global context. England: Palgrave Macmillan.

Wong, L. (2003). Why do only 5.5\% of black men marry white women? International Economic Review, 44, 803806. 